[Radiocarbon, Vol. 12, No. 1, 1970, P. 298-318]

\title{
VIENNA RADIUM INSTITUTE RADIOCARBON DATES I
}

\section{HEINZ FELBER}

Institut für Radiumforschung und Kernphysik der Österr,

Akademie der Wissenschaften, Vienna, Austria

\section{INTRODUCTION}

A dating system consisting of gas sample counter with internal anticoincidence counter ring, transistorized electronic equipment, and chemical apparatus was developed in the Institute (Felber and Vychytil, 1962; Felber, 1965). A high voltage supply Fluke Model 408B is used. For routine dating, begun in 1965, an improved $2.4 \mathrm{~L}$ counter with Teflon insulators is used, shielded on all sides by $20 \mathrm{~cm}$ of iron. The counter is run with methane at 760 torr $/ 15^{\circ} \mathrm{C}$. Spurious counts are carefully eliminated by a systematic procedure (Felber, 1966). Stability of electronics and counter is checked once a day by taking the topmost part of the peak of $\mathrm{Mn}_{\alpha}$-X-rays following electron capture in $\mathrm{Fe}-55$, radiated through a beryllium window. Checking is done with the same single channel analyzer (switched over to operation with small window) used for energy discrimination (switched over to two discriminator operation) during measurement. If any change should be observed, discriminator settings are corrected. Energy discrimination is not optimized (Felber, 1962) because a neutron generator using (d,t) reaction is run in the same building in which the samples are prepared: the lower discriminator is set above tritium maximum energy at $22 \mathrm{keV}$, the upper one at $120 \mathrm{keV}$, the highest possible energy absorption of $\mathrm{C}^{14} \beta$ particles in the special counter. The background is $1.58 \mathrm{cpm}$, the net contemporary value $(95 \%$ of NBS oxalic acid standard activity) is ca. $8.8 \mathrm{cpm}$.

After careful mechanical cleaning, excavated organic material is pretreated with hot $1 \% \mathrm{HCl}$ and hot $1 \% \mathrm{NaOH}$. Pretreated organic sample is burnt in oxygen flux; heated copper oxide completes combustion. Any excess $\mathrm{O}_{2}$ is bound on heated copper. $\mathrm{CO}_{2}$, cleaned by acidified potassium permanganate solution, is frozen out by liquid nitrogen. Shells, after mechanical cleaning, are pretreated with $\mathrm{HCl}$ to remove the surface; $\mathrm{CO}_{2}$ is liberated by $\mathrm{H}_{3} \mathrm{PO}_{4}$.

The $\mathrm{CO}_{2}$ released into an apparatus for methane synthesis is mixed with a small excess of commercial $\mathrm{H}_{2}$ (because of our discriminator setting mentioned earlier, we see no reason for selection of special tritium-free hydrogen), and circulated over heated $\left(420^{\circ} \mathrm{C}\right)$ ruthenium finely divided on aluminium oxide pellets (F. A. Baker, Newark, New Jersey). The synthesized methane is dried in a dry-ice-ethanol-cooled trap, frozen into a small steel bomb, freed from excess hydrogen by pumping, and stored for 4 weeks for the purpose of radon decay. Purity of methane is gaschromatographically checked.

Age calculations are based on a contemporary counting rate equal to 0.95 of the activity of the NBS oxalic acid standard and on a halflife for radiocarbon of $5568 \pm 30$ years. Results are given in years before 
1950 (B.P.) and in the A.D./B.c. scale. Uncertainties quoted are single standard deviations originating from the statistical nature of radioactive decay including standard, sample, background, and half-life.

In the case of old samples, if in the measuring time $\theta$ a sample net counting rate comes out smaller than three times its standard deviation, an age limit is given that corresponds to a sample net counting rate, coming out three times its standard deviation in the same measuring time. The calculation is

$$
\mathrm{t}=\frac{\tau}{\ln 2} \ln \frac{\mathrm{C}_{\mathrm{R}} \sqrt{\theta}}{\mathrm{k} \sqrt{2 \mathrm{C}_{\mathrm{L}}}},
$$

where $\tau=\mathrm{C}^{14}$ half life, $\mathrm{C}_{\mathrm{R}}=$ contemporary counting rate, $\mathrm{C}_{\mathrm{L}}=$ background counting rate, $\theta=$ measuring time, equal for contemporany standard and background, and $\mathrm{k}=3$. In the case of young samples, if in the measuring time $\theta$ the difference between contemporary counting rate and sample counting rate comes out smaller than three times the standard deviation of this difference, an age limit is given

$$
\mathrm{t}=\frac{\tau}{\ln 2} \frac{\mathrm{k}}{\mathrm{C}_{\mathrm{R}} \sqrt{\bar{\theta}}} \sqrt{\mathrm{C}_{\mathrm{R}}+2 \mathrm{C}_{\mathrm{L}}}
$$

corresponding to a sample net counting rate giving a difference equal to three times its standard deviation in the same measuring time (Felber, 1962).

No $\mathrm{C}^{13} / \mathrm{C}^{12}$ ratios were measured. Sample descriptions have been prepared in collaboration with the submitter.

The dates listed in this paper were published in Sitzungsberichtc der Österr, Akad. der Wissenschaften (Felber, 1965, 1966, 1967, 1968). As noticed in Felber, 1968, dates presented in Felber, 1965, 1966, 1967 have to be corrected because age of standard wood, used at that time, was wrong. In this date list dates are corrected and based on the NBS oxalic acid standard as mentioned above.

\section{ACKNOWLEDGMENTS}

I wish to express my gratitude to the director of the Institut für Radiumforschung und Kernphysik, B. Karlik, for her support in the establishment of the dating laboratory, and also to F. Hernegger and N. Getoff for enlightenment in the field of chemistry. Special assistance in our work was provided by the firms österreischisch-Alpine Montangesellschaft, Gebrüder Böhler Co., and Simmering-Graz-Pauker, and by Dr. F. Mayr. Aluminized foils of Hostaphan (poly therephthal acid ester) were contributed by Vacuumtechnik AG., Niederwalluf, Rheingau, West Germany.

Special thanks are due I. L. Stein, G. Oeckl, and E. Pak for their excellent work in sample preparation and operation of the dating equipment, and also A. Fritsch for gaschromatographic purity tests of synthesized methane. I am also indebted to Dipl. I. W. Attwenger and his 
staff of the electronic laboratory for planning, building, and service of electronic units.

\section{SAMPLE DESCRIPTIONS}

I. CROSS-CHECK SAMPLE

\section{VRI-6. Ruds Vedby, Denmark}

$$
11,100 \pm 200
$$

9150 B.C.

Wood from thin layer representing exact Pollen-Zone Boundary II/III, Alleröd/Younger Dryas, in profile at Ruds Vedby $\left(55^{\circ} 32^{\prime} \mathrm{N}\right.$ Lat, $11^{\circ} 22^{\prime}$ E Long), Zealand, Denmark. Comment: distributed by $\mathrm{H}$. Tauber, Copenhagen, Radiocarbon Lab., as cross-check sample and dated by many laboratories: Suess (1954), W-82, 10,260 \pm 200 ; W-84, 10,510 \pm 180; Östlund (1957a), St-18, 10,145 \pm 370; Münnich (1957), H-105-87, $11,500 \pm 300$; de Vries, Barendsen and Waterbolk (1958), GrN-454, $10,995 \pm 250$; Olsson (1959), U-20, 10,950 \pm 130, U-75, 10,810 \pm 140 ; Barker and Mackey (1959), BM-19, 11,333 \pm 200; Tauber (1953), K-101, $10,890 \pm 240$; Tauber (1960), K-101 bis, $11,090 \pm 240$; Tauber (1964), K-101 remeasured, 10,970 \pm 120 ; Alessio, Bella and Cortesi (1964), R-64, $11,900 \pm 170 ;$ Håkansson (1968), Lu-3, 10,840 \pm 120.

II. GEOLOGY, GEOGRAPHY, SOIL SCIENCE, AND FORESTRY

\section{A. Austria}

\section{VRI-127. Turracherhöhe, Kärnten}

Decomposed blackish-brown Carex-woodland peat from Schwarzseemoor near Turracherhöhe $\left(46^{\circ} 55^{\prime} \mathrm{N}\right.$ Lat, $13^{\circ} 53^{\prime}$ E Long), Carinthia, from 26 to $34 \mathrm{~cm}$ depth. Coll. 1966 by H. Mayer et al.; subm. by F. Kral, Inst. für Waldbau Hochschule für Bodenkultur, Vienna. Comment (F.K.): date fixes chronologically human influence on woodland (1st fellings in surroundings), clearly established pollen-analytically. Historically, 2 periods of fellings are suggested: one in connection with increasing iron industry (1st iron blast furnace in Turrach, 1664), another one in 13th to 14th century (pasture clearing). Date points to latter expectation.

\section{Lunz series, N.ö.}

Sphagnum peat from upland moor "Rotmösel" in Revier Neuhaus, Rothschild'sche Forstverwaltung Langau, $12 \mathrm{~km}$ SE of Lunz $\left(47^{\circ} 52^{\prime}\right.$ $\mathrm{N}$ Lat, $15^{\circ} 02^{\prime} \mathrm{E}$ Long), Lower Austria. Coll. 1966 by H. Mayer et al.; subm. by F. Kral.

\section{VRI-100. Rotmösel 8-16}

Peat from 8 to $16 \mathrm{~cm}$ depth. Comment (F.K.): dating should chronologically fix first human influence on surrounding woodland, pollenanalytically established (Kral and Mayer, 1968). If date is corrected for de Vries-effect according to Suess's table (Suess, 1965), it is not in contradiction with pollen-analytical dating. 
VRI-101. Rotmösel 32-40

Peat from 32 to $40 \mathrm{~cm}$ depth. Comment (F.K.): date unexpectedly young. Contamination possible.

\section{VRI-102. Lahnsattel, N.ö.}

Carr peat from small woodland moor at edge of primeval forest reservation "Neuwald" ca. $2 \mathrm{~km}$ E of Lahnsattel $\left(47^{\circ} 46^{\prime} 30^{\prime \prime} \mathrm{N}\right.$ Lat, $15^{\circ} 29^{\prime} 10^{\prime \prime}$ E Long), Lower Austria. Sample from 15 to $23 \mathrm{~cm}$ depth. Coll. 1966 by H. Mayer et al.; subm. by F. Kral. Comment (F.K.): dating should chronologically fix lst human influence on surrounding woodland, pollen-analytically established (Kral and Mayer, 1968). If date is corrected for de Vries-effect according to Suess's table (Suess, 1965), it is not in contradiction with pollen-analytical dating.

\section{Litschau series, N.ö.}

Dark-brown carr peat from Rottalmoos near Litschau $\left(48^{\circ} 57^{\prime} \mathrm{N}\right.$ Lat, $15^{\circ} 03^{\prime} \mathrm{E}$ Long), Waldviertel, Lower Austria. Coll. 1966 by H. Mayer et al.; subm. by F. Kral.

\section{VRI-125. Litschau 4-12}

$730 \pm 70$

Peat from 4 to $12 \mathrm{~cm}$ depth. Comment (F.K.): date fixes pollenanalytically established beginning of human influence on surrounding woodland. Date in agreement with submitter's estimate.

\section{VRI-126. Litschau 25-33}

$4110 \pm 90$

\section{Peat fron 25 to 33 ch depth. Comment (F.K.): date fxes poll.} analytically established beginning of increased spread of Abies. Date in agreement with submitter's estimate.

VRI-18. Linz a. Donau, O.ö.

$4620 \pm 120$

2670 B.C.

Stem, dredged from fluvial deposits of Danube during construction of tankage port West, Linz $\left(48^{\circ} 18^{\prime} \mathrm{N}\right.$ Lat, $14^{\circ} 18^{\prime} \mathrm{E}$ Long), Upper Austria. Coll. 1962; subm. by Stadtmuseum, Linz. Comment: date disproves estimate of 10,000 to $15,000 \mathrm{yr}$.

\section{Mondsee series 1, 0. ̈.}

Subm. by W. Klaus, Geol. Bundesanstalt, Vienna.

\section{VRI-31. Mondsee 1}

Subfossil wood (Picea) excavated at Autobahn Salzburg-Vienna, km

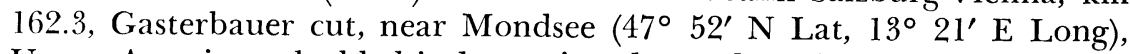
Upper Austria, embedded in lacustrine clay and sand in region of Würm moraine of Ice Age Traun glacier. Coll. 1960 by J. Schadler. Comment (W.K.): problem was to distinguish between Alleröd, a Würm interstadial, and Riss-Würm Interglacial. Pollen-analytical result points to Riss-Würm Interglacial. Date not in contradiction. 
VRI-39. Mondsee 2

Fossil wood from Taxus baccata, Picea, and supposed Angiosperms, fossil Picea cones, excavated from plant-bearing layer in lacustrine clay in cut of rivulet Steinerbach ca. $50 \mathrm{~m}$ above pier of Mondsee-Autobahnbridge near Mondsee. Lacustrine clay lies on ground moraine. Coll. 1965 by W. Klaus. Comment (W.K.): pollen-analytically Riss-Würm Interglacial is supposed. Date not in contradiction.

\section{Unterach series, O.ö.}

Samples from big stems in bluish-gray lacustrine clay excavated 40 $m$ above level of lake Attersee, near crossing SonnwendbühelstrasseUmfahrungsstrasse, Unterach $\left(47^{\circ} 49^{\prime} \mathrm{N}\right.$ Lat, $13^{\circ} 29^{\prime} \mathrm{E}$ Long), Upper Austria. Coll. 1966 by E. Koller; subm. by W. Freh, O. Ö Landesmus., Linz.

General Comment (W.F.): frequent excavations of big stems in this area together with geologic state suggest large landslip in Flysch of Hochplettenspitze by which forest was pushed into interglacial lake. Dates disprove estimate.

VRI-90. Unterach 1

Sample from Stem 1.

VRI-91. Unterach 2

Sample from Stem 2.
A.D. 600

$1290 \pm 80$

A.D. 660

VRI-128. Schneegattern, O.̈̈.

Moderately decomposed Sphagnum peat from Sieglmoos near Schneegattern (48 $01^{\prime} \mathrm{N}$ Lat, $13^{\circ} 17^{\prime} \mathrm{E}$ Long), Upper Austria, Kobernauserwald, from 28 to $36 \mathrm{~cm}$ depth. Coll. 1966 by H. Mayer et al.; subm. by F. Kral. Comment (F.K.): relative young upland moor. Date should fix anthropogeneous influence on woodland clearly established by pollen-analyses. Date too young. Contamination by Cyperaceae roots.

VRI-129. Wenigzell-Sommersgut, Stmk.

$6390 \pm 110$

Decomposed black wood peat from ca. $2 \mathrm{~m}$ thick upland moor near Wenigzell-Sommersgut (47 $27^{\prime} \mathrm{N}$ Lat, $15^{\circ} 47^{\prime} \mathrm{E}$ Long), Styria. Depth 46 to $54 \mathrm{~cm}$. Coll. 1967 by K. Zukrigl; subm. by F. Kral. Comment (F.K.): date fixes pollen-analytically established spread of Abies. Date in agreement with submitter's expectation.

\section{VRI-130. W enigzell-Sichart, Stmk.}

$2810 \pm 80$

Decomposed brownish-black wood peat from 1.2-m-thick transitional moor near Wenigzell-Sichart (47 $27^{\prime} \mathrm{N}$ Lat, $15^{\circ} 47^{\prime} \mathrm{E}$ Long), Styria. Depth 61 to $69 \mathrm{~cm}$. Coll. 1967 by K. Zukrigl; subm. by F. Kral. Comment (F.K.): dates fixes pollen-analytically established beginning of anthropo- 
geneous influence on woodland (earlier Picea-Abies-Fagus, today PiceaPinus). Date in agreement with expectation.

\section{Fernauferner series, Tirol}

Samples from Buntes Moor ( $46^{\circ} 59^{\prime} 27^{\prime \prime}$ N Lat, $11^{\circ} 08^{\prime} 45^{\prime \prime}$ E Long), at $+2290 \mathrm{~m}$, Fernauferner, Stubai Valley, Tyrol, coll. in shaft surrounding Aario's profile (Aario, 1945). Depths given are below surface of bog. Coll. 1962 and subm. by F. Mayr, Geog. Inst., Univ. of Innsbruck.

\section{VRI-8. Fernauferner 1}

Pieces of wood, (Pinus cembra, Alnus cf. viridis, det. W. Larcher, Innsbruck) from bottom, depth $4.20 \mathrm{~m}$ (Aario's profile Fig. 2, depth $3.4 \mathrm{~m}$ ). Comment (F.M.): sample dates ice-avalanches and postglacial maximum of a little unnamed glacier SE of Buntes Moor. At the same time, Fernauferner remained behind its post-Altithermal maximum.

\section{VRI.9. Fernauferner 2}

Pieces of wood near bottom, depth $4.20 \mathrm{~m}$ (Aario's profile, Fig. 2, depth $3.20 \mathrm{~m}$ ). Comment (F.M.): sample coll. in ground-moraine-like altered layer of gyttja with sharp boundaries. It dates last ice-avalanches which came from glacieret SE of Buntes Moor.

\section{VRI-10. Fernauferner 3}

$3150 \pm 120$ 1200 B.c.

Pieces of wood from silt layer, depth $2.90 \mathrm{~m}$ (Aario's profile, Fig. 2, depth $2.10 \mathrm{~m}$ ). Comment (F.M.): silt layer was deposited immediately after 1st post-Altithermal maximum of Fernauferner, on remains of Moorstauchmoräne.

\section{VRI-11. Fernauferner 4}

$1890 \pm 120$

Peat (sedges and Hypnaceae?) from thin peat layer between sand layers, depth $0.95 \mathrm{~m}$ (Aario's profile, Fig. 2, depth $0.65 \mathrm{~m}$ ). Comment (F.M.): peat layer is maximum for 2nd Moorstauchmoräne of Fernauferner, $50 \mathrm{~m} \mathrm{~W}$ of shaft. This moraine is latest link in series of glacier advances during Zone $\mathrm{Xb}$ time.

\section{VRI-13. Fernauferner 6}

Peat (sedges and Hypnaceae?) from $2 \mathrm{~cm}$ peat layer, depth $2.45 \mathrm{~m}$ (Aario's profile, Fig. 2, depth $1.92 \mathrm{~m}$ ). Comment (F.M.): peat layer beneath long-term accumulation of Zone IX time.

\section{VRI-14. Fernauferner 7}

Peat (sedges and Hypnaceae?) from $2 \mathrm{~cm}$ peat layer between sandy series, depth $1.85 \mathrm{~m}$ (Aario's profile, Fig. 2, depth $1.50 \mathrm{~m}$ ). Comment (F.M.): in this peat layer herbaceous and Salix pollen grains reached extreme maxima. It is supposed to correspond with short but intensive. retreat of Fernauferner. 
VRI-15. Fernauferner 8

Peat (sedges and Hypnaceae?) from lowest $2 \mathrm{~cm}$ of 12 to $15 \mathrm{~cm}$ peat layer, depth 1.20 (Aario's profile, Fig. 2, depth $0.78 \mathrm{~m}$ ). Comment (F.M.): sample is maximum of Zone $\mathrm{IXb} / \mathrm{Xa}$ boundary. Peat of $\mathrm{Xa}$ as well as sediments of IXa and IXb are incorporated into Moorstauchmoräne of Zone $\mathrm{Xb}$ time.

\section{Kaunertal series, Tirol}

Pieces of wood washed into sand deposits of rivulet Fagge. Samples taken in surroundings of dam project Griesboden $\left(46^{\circ} 56^{\prime} \mathrm{N}\right.$ Lat, $10^{\circ}$ $45^{\prime}$ E Long), Tirol, from different depths by boring. Subm. by Tiroler Wasserkraftwerke A.G.

VRI-32. Borehole C 11

$9390 \pm 160$

Depth $35.80 \mathrm{~m}$. Coll. 1965 by Rudan and Schmidegg.

VRI-33. Borehole A 3

$5990 \pm 140$

Depth $6.50 \mathrm{~m}$. Coll. 1964 by Schmidegg.

4040 B.C.

VRI-34. Borehole South A 3

$8520 \pm 160$

6570 B.C.

Wood-bearing layer with black soil. Coll. 1964 by Schmidegg.

\section{VRI-35. Jägerhaus}

$9370 \pm 160$

7420 B.c.

Wood embedded in sands from wall near research Drift W. Depth $1 \mathrm{~m}$. Coll. 1964 by Zischinsky.

\section{Venediger Group Series 1, Osttirol}

Different samples from mountain group Venediger in East Tyrol. Coll. 1965 and subm. by G. Patzelt, Geog. Inst., Univ. of Innsbruck.

\section{VRI-54. Venediger Group 1965/1}

Thin roots between detritus of ground moraine below $1.20 \mathrm{~m}$ peat, $10 \mathrm{~m}$ before old end moraine of Simonykees near Rostockerhütte $\left(47^{\circ}\right.$ $03^{\prime} 19^{\prime \prime} \mathrm{N}$ Lat, $12^{\circ} 18^{\prime} 07^{\prime \prime} \mathrm{E}$ Long). Comment (G.P.): date is minimum for end moraine of Simonykees, 50 to $150 \mathrm{~m}$ before younger lateral moraines of joined Simony- and Maurerkees.

\section{VRI-55. Venediger Group 1965/2}

$8720 \pm 150$

Branches from base of $2.3 \mathrm{~m}$ thick peat layer, ca. $400 \mathrm{~m}$ above timber line. Avalanche-preserved position, $100 \mathrm{~m}$ above Rostockerhütte $\left(47^{\circ}\right.$ $03^{\prime} 15^{\prime \prime} \mathrm{N}$ Lat, $12^{\circ} 17^{\prime} 56^{\prime \prime} \mathrm{E}$ Long). Comment (G.P.): date is minimum of postglacial Altithermal period in Alps. 
VRI-56. Venediger Group 1965/3

$6130 \pm 130$

Sample from wood horizon at base of 80 -cm-thick, undisturbed peat layer between 2 oldest end moraines of Frossnitzkees, at $+2225 \mathrm{~m}\left(47^{\circ}\right.$ $04^{\prime} 33^{\prime \prime} \mathrm{N}$ Lat, $12^{\circ} 26^{\prime}$ 59" E Long), near puddle "Auf der Achsel”. Comment (G.P.): date is minimum of inner of the 2 moraines.

\section{VRI-57. Venediger Group 1965/4}

$7570 \pm 140$

Split branches in and above folded silt below $1.6 \mathrm{~m}$ peat immediately before outer postglacial end moraine. Avalanche-preserved position, Dorferkees at $+2170 \mathrm{~m}\left(47^{\circ} 03^{\prime} 55^{\prime \prime} \mathrm{N}\right.$ Lat, $12^{\circ} 20^{\prime} 19^{\prime \prime}$ E Long). Comment (G.P.): date gives age of greatest postglacial maximum of Dorferkees.

\section{VRI-58. Venediger Group 1965/5}

$5500 \pm 140$ 3550 в.C.

Fragments of tree (felled by avalanches) at base of 2-m-thick organic deposits. Avalanche tracks at opposite slope. Obersulzbachkees, at $+1750 \mathrm{~m}\left(47^{\circ} 08^{\prime} 30^{\prime \prime} \mathrm{N}\right.$ Lat, $12^{\circ} 16^{\prime} 49^{\prime \prime} \mathrm{E}$ Long). Comment (G.P.): sample dates oldest of 4 periods of increased avalanche activity established in profile.

\section{Venediger Group Series 2, Osttirol}

Cyperaceae peat from moor near Rostockerhütte $\left(47^{\circ} 03^{\prime} 19^{\prime \prime}\right.$ N Lat, $12^{\circ} 18^{\prime} 07^{\prime \prime}$ E Long), at $+2270 \mathrm{~m}$, Maurer Valley, S Venediger Group, Hohe Tauern, East-Tyrol. Peat layer $2.3 \mathrm{~m}$ thick without detectable growth disturbance. Coll. 1967 and subm. by G. Patzelt.

\section{VRI-111. Venediger $1968 / 1$}

$8340 \pm 130$

Depth 206 to $209 \mathrm{~cm}$. Comment (G.P.): sample dates NAP peak of pollen diagram indicating climate deterioration. Advance of Simony glacier.

VRI-112. Venediger $1968 / 2$

$8040 \pm 120$

Depth 175 to $178 \mathrm{~cm}$. Comment (G.P.): same as VRI-111.

\section{VRI-131. Venediger $1968 / 3$}

$6400 \pm 100$

Depth 107 to $110 \mathrm{~cm}$. Comment (G.P.): sample dates NAP peak of pollen diagram indicating climate deterioration. Advance of Frossnitz glacier.

VRI-132. Venediger $1968 / 4$

$4580 \pm 90$ 2630 B.c.

Depth 53 to $57 \mathrm{~cm}$. Comment (G.P.): pollen spectrum indicates slight climate deterioration. No glacier advance in Venediger Group could be observed in this period. 
VRI-133. Venediger $1968 / 5$

Depth 33 to $37 \mathrm{~cm}$. Comment (G.P.): pollen profile clearly indicates climate deterioration. Advance for Frossnitzkees and other Alpine glaciers was dated for same period.

\section{Kälbertal series, Tirol}

Wood samples from sediment fill of former puddle at exit of Kälbertal ( $47^{\circ} 22^{\prime} 00^{\prime \prime} \mathrm{N}$ Lat, $10^{\circ} 49^{\prime} 10^{\prime \prime}$ E Long), Tyrol, belonging to Fernpass landslide (Abele, 1964; Mayr, 1968). Coll. 1965 and subm. by F. Mayr.

\section{VRI-47. Kälbertal 1}

$$
2580 \pm 90
$$

Wood from base of sediment fill. Comment (F.M.): sample dates cut-off of Kälbertal by landslide.

\section{VRI-48. Kälbertal 2}

$2370 \pm 90$

Picea wood from upper edge of sediment fill. Comment (F M): sample permits estimation of material transport by rivulet for longer period.

\section{Grünauferner series, Tirol}

Wood samples from Grünauferner forefield $\left(46^{\circ} 59^{\prime} 50^{\prime \prime} \mathrm{N}\right.$ Lat, $11^{\circ} 11^{\prime} 37^{\prime \prime}$ E Long), Tyrol, at +2190 m (Mayr, 1964, 1968b). Coll. 1965 and subm. by $\mathrm{F}$. Mayr.

\section{VRI-50. Griinauferner 1}

Branch of tree (Pinus pumilio?) in sand at base of peat, $2.5 \mathrm{~m}$ thick, $30 \mathrm{~m}$ in front of end moraines of Grünauferner. Position safe from avalanches. Comment (F.M.): oldest evidence of dwarf mountain fir in forefield of Grünauferner. Dates recolonization after oldest Larstig-maximum (Patzelt, VRI-54, VRI-57, this date list), consequently, greatest Postglacial maximum of Grünauferner.

\section{VRI-51. Grünauferner 2}

$6710 \pm 130$

Stem wood at outer edge of nearly wood-free Moorstauchmoräne, $25 \mathrm{~m}$ in front of younger end moraine of Grünauferner. Position safe from avalanches. Comment (F.M.): like VRI-8 and VRI-9 date demonstrates that between oldest and youngest Larstig-maximum (Patzelt, VRI56, VRI-57) Alpine treeline was higher than today. Moorstauchmoräne (Mayr, 1968b) is not dated.

\section{VRI-52. Innsbruck-Amras, Tirol}

$$
570 \pm 80
$$

Alnus fragments, depth $1.5 \mathrm{~m}$, near Autobahn junction Innsbruck-

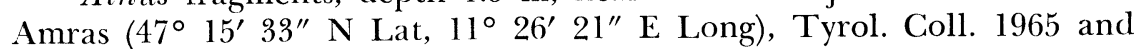
subm. by F. Mayr. Comment (F.M.): Alnus fragments are slightly older 
than youngest undercut of alluvial cone of R. Sill and terraces of ice cake near Amras.

\section{Stillup Valley series, Tirol}

Roots or stemwood fragments in fine-sand fill in Stillup Valley $\left(47^{\circ} 07^{\prime} \mathrm{N}\right.$ Lat, $11^{\circ} 52^{\prime} \mathrm{E}$ Long), Zillertaler Alpen, Tyrol, taken from different depths in boring A2. Coll. 1966 and subm. by Mignon, Tauernkraftwerke A. G., Mayrhofen.

\section{VRI-95. Stillup 1}

Depth 7 to $11 \mathrm{~m}$.

VRI-96. Stillup 2

Depth 13 to $14 \mathrm{~m}$.

\section{$1460 \pm 80$ A.D. 490}

$$
2210 \pm 80
$$$$
260 \text { B.C. }
$$

$4960 \pm 100$ 3010 B.C.

\section{VRI-98. Roppen, Tirol}

Charcoal (Larix decidua), taken near easternmost turn of newly built forest road to spring of rivulet Leonhardsbach, at $+880 \mathrm{~m}$, SSE above Roppen $\left(47^{\circ} 13^{\prime} \mathrm{N}\right.$ Lat, $10^{\circ} 49^{\prime} \mathrm{E}$ Long), gorge of ötz Valley, Tyrol. Inner slope of Gschnitz lateral moraine of ötztal glacier (Heuberger, 1966). Stratification disturbed by movements along steep slope $\left(30^{\circ}\right.$ to $\left.40^{\circ}\right)$ supposedly consequence of forest fire. Burned horizon and former soil was kneaded into Tschirgant landslide moraine material. Landslide moraine is Younger Dryas. Coll. 1967 and subm. by H. Heuberger, Geog. Inst., Univ. of Innsbruck. Comment (H.H.): originally, submitter supposed disturbance of profile resulted from glacier activity, suggested by comparison with neighboring profiles, and hoped to date the pre-advance forest. Date proves that burned horizon was created on landslide moraine and hence is not pre-moraine. Date given by M. Rubin, W-2082: $4780 \pm 300$ (Radiocarbon, v. 12, p. 333) in excellent agreement.

\section{Roppen series, Tirol}

Charcoal from horizons of disturbed, buried fossil soil between 2 Late-glacial moraines of ötz Valley glacier, mouth of ötz Valley, Tyrol, new forest road (1967) SE above Roppen (47 $13^{\prime} \mathrm{N}$ Lat, $10^{\circ} 49^{\prime} \mathrm{E}$ Long), easternmost curve, at ca. $+880 \mathrm{~m}$. Older moraine contains only crystalline material of Central Alps. Younger (upper) moraine is rich in limestone of Tschirgant landslide, covering end of glacier tongue. Coll. 1968 by H. Heuberger, I. Neuwinger, and G. Heiss; subm. by Heuberger.

General Comment (H.H.): supposedly soil containing charcoal was formed in interstadial between 2 advances of ötz Valley glacier. Length of former ötz Valley glacier excludes younger date than Alleröd. The very young charcoal dates show that buried soil was not only disturbed by overriding glacier but also by later colluvial movements along $30^{\circ}$ to $40^{\circ}$ steep slope. 
VRI-122. Roppen A

Charcoal from top horizon (burned; A horizon?)

VRI-123. Roppen B

$3000 \pm 350$

Charcoal from B horizon.

VRI-17. Galtuir, Paznauntal, Tirol

$990 \pm 100$

Charcoal from burned soil horizon ca. $35 \mathrm{~cm}$ below A horizon of podsolic brown earth. Galtür $\left(46^{\circ} 59^{\prime} \mathrm{N}\right.$ Lat, $10^{\circ} 12^{\prime} \mathrm{E}$ Long), Tyrol, N slope of Predigtberg, Silvretta Group, ca. +1800 m. Coll. 1959 by G. Heiss; subm. by I. Neuwinger, Forstliche Bundesversuchsanstalt, Bodenkundliches Labor, Imst. Comment (I.N.): had been thought to belong to a forest-fire period in Bronze age, early Hallstatt, or early Middle ages. Date points to latter.

ötz Valley series, Tirol

Charcoal from burned-soil horizons from ötz Valley, Tyrol. Subm. by I. Neuwinger.

General Comment: dates fix burning horizon chronologically and give clue to soil genesis.

\section{VRI-76. Obergurgl 1}

$1900 \pm 80$

Charcoal from burning horizon above colluvial erosion horizon in podsolic brown earth, ca. $15 \mathrm{~cm}$ below contemporary humus horizon. Surroundings of Obergurgl $\left(46^{\circ} 52^{\prime} \mathrm{N}\right.$ Lat, $11^{\circ} 02^{\prime} \mathrm{E}$ Long), from Verwallbach in direction of Königstal, to Forstliche Bundesversuchsanstalt Sta., at $+1980 \mathrm{~m}$. Coll. 1965 by M. Doenecke.

VRI-78. Obergurgl 2

$2060 \pm 200$

Charcoal from burning horizon in iron podsol, ca. $25 \mathrm{~cm}$ below contemporary humus horizon, Obergurgl, "Zirbenwald", at +2060 m. Coll. 1965 by M. Doenecke.

VRI-75. Obergurgl 3

$$
650 \pm 70
$$

Charcoal from burning horizon in contemporary iron-humus podsol ca. $25 \mathrm{~cm}$ below contemporary humus horizon, $50 \mathrm{~m} \mathrm{~S}$ of Sta. Obergurgl of Forstliche Bundesversuchsanstalt, Gurgler Heide, at $+2080 \mathrm{~m}$. Coll. 1965 by M. Doenecke. Comment (I.N.): charcoal from neighboring locality was dated by K. O. Münnich: $2460 \pm 90$ (H-365-507).

VRI-77. GurgI

$1540 \pm 80$

Charcoal in burning horizon in iron podsol, ca. 20 to $25 \mathrm{~cm}$ below contemporary humus horizon, above eluvial $A_{e}$ horizon from older podsol. NE slope of Beerrinne in area of Sta. Gurgl $\left(46^{\circ} 53^{\prime} \mathrm{N}\right.$ Lat, $11^{\circ} 02^{\prime}$ E Long) of Forstliche Bundesversuchsanstalt, at $+1980 \mathrm{~m}$. Coll. 1965 by I. Neuwinger. 
VRI-16. Eggenstall ob St. Leonhard, Pitz Valley, Tirol

Charcoal from burned-soil horizon below $20 \mathrm{~cm}$ of contemporary raw humus, Eggenstall ob St. Leonhard $\left(47^{\circ} 04^{\prime} \mathrm{N}\right.$ Lat, $10^{\circ} 51^{\prime} \mathrm{E}$ Long), Pitz Valley, Ötztaler Alpen, Tyrol, ca. $+2000 \mathrm{~m}$. Coll. 1959 and subm. by I. Neuwinger. Comment (I.N.): had been thought to belong to a forest-fire period in Bronze age, early Hallstatt, or early Middle ages. Date points to latter.

\section{Pitz Valley series, Tirol}

Charcoal samples from burning horizons in soil, Pitz Valley, ötztaler Alpen, Tyrol (Fromme, 1957). Coll. 1965 and subm. by I. Neuwinger. General Comment: dates fix burning horizons chronologically and give clue to soil genesis.

VRI-79. Pitz Valley end

A.D. 1060

$890 \pm 80$

Charcoal from burning horizon in podsolic brown earth (Kubiena), 15 to $25 \mathrm{~cm}$ below contemporary humus horizon above colluvial erosion horizon and eroded B horizon from former podsol. End of Pitz Valley, footpath from Taschachalm $\left(46^{\circ} 57^{\prime} \mathrm{N}\right.$ Lat, $10^{\circ} 51^{\prime} \mathrm{E}$ Long) to lake Riffelsee, $+1950 \mathrm{~m}$. Comment (I.N.): burning horizons are found in area of Taschachalm, a very old pasture land.

\section{VRI-80. Pitz Valley, St. Leonhard}

$1180 \pm 80$

Charcoal in burning horizon, in eroded iron podsol, partially lying open after road works, at other localities ca. $15 \mathrm{~cm}$ below contemporary humus. Pitz Valley, forest road from St. Leonhard $\left(47^{\circ} 04^{\prime} \mathrm{N}\right.$ Lat, $10^{\circ}$ $51^{\prime}$ E Long) to Neubergalm, at $+1750 \mathrm{~m}$.

\section{VRI-94/1. Fritzens, Tirol}

$$
\begin{gathered}
11,370 \pm 150 \\
9420 \text { в.C. }
\end{gathered}
$$

Wood from tree trunk, 20 to $30 \mathrm{~cm}$ thick, and much more pressed and carbonized than in comparable Postglacial landslides, embedded in stratified flow-silt, together with striated pebbles and weathered pieces of Triassic limestone. Clay pit Fritzens $\left(47^{\circ} 18^{\prime} 25^{\prime \prime} \mathrm{N}\right.$ Lat, $11^{\circ} 34^{\prime} 19^{\prime \prime}$ E Long), Tyrol, $0.5 \mathrm{~m}$ below present surface. Coll. 1966 and subm. by F. Mayr. Comment (F.M.): submitter assumed greater age, the interstadial between Mils and Würm (Mayr, 1968a). When date did not agree, a 2nd date: VRI-94/2 gave $11,200 \pm 150$.

\section{VRI-92. Dölsach, Osttirol}

$$
2130 \pm 80
$$

See III A.

180 B.C.

VRI-103. Feldkirch, Vorarlberg

$10,110 \pm 140$

Stem wood (Pinus) with tooth marks of beaver, embedded in Rhine Valley alluvium, at depth $18 \mathrm{~m}$ in ballast pit, Feldkirch $\left(47^{\circ} 14^{\prime} \mathrm{N}\right.$ Lat, 
$09^{\circ} 38^{\prime}$ E Long), Vorarlberg. Coll. 1967 by E. Vonbank; subm. by R. Pittioni, Inst. für Ur- und Frühgeschichte, Univ. of Vienna. Comment (R.P.): age should be younger than last glacial epoch because Rhine Valley glacier there extended as far as Lake Constanz. Established age points to Alleröd.

\section{B. Europe}

VRI-27. Lieth near Elmshorn, West Germany

Tree branches from peat near Lieth bei Elmshorn $\left(53^{\circ} 46^{\prime} \mathrm{N}\right.$ Lat, $09^{\circ} 40^{\prime}$ E Long), West Germany. In Alleröd deposits. Subm. by R. Pittioni. Comment (R.P.): date consistent with expectation.

\section{VRI-53. Hörmating, West Germany}

Driftwood from water-laid sediments lacking fossils, intersected by networks of loam-filled frost cracks, several $\mathrm{m}$ deep, and covered by Würm ground moraine (Ebers, 1963). Hörmating, Oberbayern, Grüner Turm I ( $47^{\circ} 56^{\prime} 57^{\prime \prime} \mathrm{N}$ Lat, $12^{\circ} 01^{\prime} 03^{\prime \prime} \mathrm{E}$ Long), West Germany. Coll. 1965 and subm. by F. Mayr. Comment (F.M.): wood is older than frost cracks, formed when Inn glacier of Würm age arrived at locality. See also W-1002 (Radiocarbon, 1964, v. 6, p. 70).

\section{VRI-106. Mont Blanc, Italy}

Wood at base of pool sediments $1.4 \mathrm{~m}$ below bank of debris. Mt. Blanc S side, Alpe Lex Blanche inferieur, $2150 \mathrm{~m}$, Val Veni, Aosta ( $45^{\circ} 43^{\prime} \mathrm{N}$ Lat, $07^{\circ} 19^{\prime} \mathrm{E}$ Long), Italy. Coll. 1967 and subm. by F. Mayr. Comment (F.M.): formation of bank and pool were forced by Postglacial maximum of Glacier de la Lex Blanche and Glacier d'Estellette. Sample dates beginning of bank formation.

\section{VRI-107. Mont Blanc, France}

$6400 \pm 100$

Wood from ca. $12 \mathrm{~m}$ below surface of former Sandur. Sample from bog covered at greatest Postglacial glacier maximum. Mont Blanc $\mathrm{N}$ side, Montroc near Argentière, Valley of Chamonix, $300 \mathrm{~m} \mathrm{NE}$ of bridge, Pt. 1363 m, (45 59' 51.1" N Lat, 06 ${ }^{\circ} 56^{\prime}$ 15.6" E Long), France. Coll. 1967 and subm. by F. Mayr. Comment (F.M.): sample is unique in that it dates the greatest Postglacial maximum of the great glaciers on $\mathbf{N}$ slope of Mt. Blanc. Interpretation and date in excellent agreement (Mayr, 1969).

\section{ARCHAEOLOGIC SAMPLES}

\section{A. Austria}

VRI-4. Vienna 1

Wood from propping post of Wall 41 in 2nd basement of former House Berghof 3, later annexed to Hoher Markt 8, Vienna I. Basement was situated below Roman Pavement f. Coll. 1962 and subm. by Hertha 
Ladenbauer-Orel, Bundesdenkmalamt, Vienna. Comment (H.L.): 2nd basement was built after Roman pavement between 1st (1529) and 2nd (1683) siege of Vienna by the Turks, as was concluded from excavation.

VRI-5. Vienna 2

A.D. 1050

$900 \pm 150$

Wood from walled post propping stone Wall 16 of 1st basement of House Sterngasse 7, Vienna I. Coll. 1962 and subm. by H. LadenbauerOrel. Comment (H.L.): Gothic house was built ca. A.D. 1200.

VRI-19. Vienna 3

A.D. 1500

$450 \pm 90$

Wood fragments from coffin or chest in vault below Gothic pavement, excavated in church "Am Hof," Vienna I. Skeleton covered with calcareous layer and humus. No artifacts. Coll. 1964 and subm. by G. Mossler, Bundesdenkmalamt, Vienna.

\section{VRI-41. Loretto, Burgenland}

$2990 \pm 120$

Charcoal from pyre of Hallstattian burial at reed "Ochsenstand," $\mathrm{N}$ slope of Leitha-Gebirge, Site 83, Loretto $47^{\circ} 55^{\prime} \mathrm{N}$ Lat, $16^{\circ} 31^{\prime} \mathrm{E}$ Long), Burgenland. Excavation with obtuse, cone-shaped pyre, placed near middle at bottom of grave, $1.10 \mathrm{~m}$ deep, together with vessels filled with fragments of vessels and sand-humus mixture. Filling disturbed by younger burial of La Tène (skeleton) to depth of $50 \mathrm{~cm}$. Surface: sand with humic layer. Coll. 1955 and subm. by A. J. Ohrenberger, Burgenländisches Landesmus., Eisenstadt.

\section{VRI-42. Unterpullendorf, Burgenland}

$6130 \pm 140$

Charcoal in filling material of Neolithic Refuse Pit 1 in loam-sand soil, irregular in form, ca. $5 \times 5 \mathrm{~m}^{2}$, at depth $1 \mathrm{~m}$. Humus filling mixed with painted ceramic fragments, small flints, Grünstein-tool fragments, animal bones, and charcoal. Relatively clean charcoal in some parts of pit. Filling covered with 10 to $15 \mathrm{~cm}$ humus. Unterpullendorf, Dist. Oberpullendorf $\left(47^{\circ} 30^{\prime} \mathrm{N}\right.$ Lat, $16^{\circ} 30^{\prime} \mathrm{E}$ Long), Burgenland. Coll. 1964 and subm. by A. J. Ohrenberger. Comment (A.O.): typologically early phase in Neolithic "Bemaltkeramische Kultur" (Pittioni, 1954; Novotny, 1962) is estimated. Date agrees with expectation.

\section{VRI-104a. Unterpullendorf, Burgenland}

$5940 \pm 100$

3990 B.c.

Charcoal in filling material of Neolithic Refuse Pit 2, $10 \times 12$ $\mathrm{m}^{2}$, depth $1.6 \mathrm{~m}$, Neolithic dwelling place $\mathrm{E}$ of Unterpullendorf Dist. Oberpullendorf ( $47^{\circ} 30^{\prime} \mathrm{N}$ Lat $16^{\circ} 30^{\prime} \mathrm{E}$ Long), Burgenland, at $\mathrm{N}$ slope in floated loess. Sample taken from 100 to $140 \mathrm{~cm}$ depth; subsoil water. Coll. 1967 and subm. by A. J. Ohrenberger. Comment (A.O.): chronologically homogeneous filling consists of ceramic fragments, stone tools. few bones, much charcoal. Pit 2, $80 \mathrm{~m} \mathrm{E}$ of Pit 1 (VRI-42) belongs to same culture as Pit 1 (Quitta, 1967). Date agrees with expectation. 


\section{VRI-105. Müllendorf, Burgenland}

Charcoal from Bronze Age Refuse Pit, $2.4 \times 3.0 \mathrm{~m}^{2}$, depth $1.3 \mathrm{~m}$, Müllendorf ( $47^{\circ} 50^{\prime} \mathrm{N}$ Lat, $16^{\circ} 27^{\prime} \mathrm{E}$ Long), Burgenland, near r.r. sta. at S slope of Leithagebirge. Coll. 1967 and subm. by A. J. Ohrenberger. Comment (A.O.): many ceramic fragments, animal bones, and charcoal. Stony soil. Date agrees with typologically expected age.

\section{VRI-97. St. Veit a.d. Glan, Kärnten}

Charred wood from Roman building excavated at Magdalensberg, at $+950 \mathrm{~m}, \mathrm{E} \mathrm{mt}$. border of Zollfeld, surroundings of St. Veit a.d. Glan ( $46^{\circ} 46^{\prime} \mathrm{N}$ Lat, $14^{\circ} 21^{\prime} \mathrm{E}$ Long), Carinthia. Supposedly construction of bake-oven. Coll. 1967 and subm. by Gertrud Mossler. Comment (G.M.): date agrees with etxpectation.

\section{VRI-25. Horn, N.ö.}

Charcoal from Hallstatt cultural layer in brickyard Thalhammer near Horn $\left(48^{\circ} 40^{\prime} \mathrm{N}\right.$ Lat, $15^{\circ} 40^{\prime} \mathrm{E}$ Long), Lower Austria. Coll. 1960; subm. by R. Pittioni. Comment (R.P.): date agrees with expectation.

\section{VRI-59. Inzersdorf ob der Traisen, N.ö.}

$$
2180 \pm 90
$$

Charcol trom fireplace (Herdgrube 108) in situ, $80 \mathrm{~cm}$ clep, Inzersdorf ob der Traisen $\left(48^{\circ} 19^{\prime}\right.$ N Lat, $15^{\circ} 41^{\prime}$ E Long), K. G. Walpersdorf, Lower Austria, Parzelle No. 170, Ballast Pit K. Handl. Coll. 1965 by C. Eibner; subm. by R. Pittioni. Comment (R.P.): La Tène B-C postbuilding; graphite ceramics. Date agrees with expectation.

\section{VRI-60. Trasdorf, Ger. Bez. Tulln, N.ö.}

$$
2240 \pm 90
$$

Charcoal from ground plan of late Hallstattian house, Trasdorf $\left(48^{\circ}\right.$ $19^{\prime} \mathrm{N}$ Lat, $15^{\circ}$ 53' E Long), Lower Austria. Coll. 1964 by E. Lucius; subm. by R. Pittioni. Comment (R.P.): date not in agreement with expectation.

\section{VRI-61. Gars-Thunau, N.ö.}

$$
840 \pm 70
$$

Charcoal from post of $\mathrm{N}$ rampart of bulwark (Friesinger and MitschaMärheim, 1968) built above older grave field. Gars-Thunau, Bez. Horn (48 $40^{\prime} \mathrm{N}$ Lat, $15^{\circ} 40^{\prime} \mathrm{E}$ Long), Lower Austria. Coll. 1965 by H. Friesinger; subm. by R. Pittioni. Comment (R.P.): grave field belongs to middle of 9 th century. Bulwark erection ca. A.D. 900 is expected.

VRI-62. Sommerein, N.ö.

$$
1380 \pm 80
$$

\section{A.D. 570}

Charcoal excavated from ground plan of hut, $60 \mathrm{~cm}$ deep, in Brucker Pforte between villages Sommerein and Götzendorf $\left(48^{\circ} 01^{\prime} \mathrm{N}\right.$ Lat, $16^{\circ}$ 35' E Long), Lower Austria, Parzelle 4517/1. Coll. 1962 by H. Friesinger; 
subm. by R. Pittioni. Comment (R.P.): last 3rd of 9th century was expected.

\section{Gaiselberg series, N.ö.}

Samples excavated at Gaiselberg ( $48^{\circ} 32^{\prime} \mathrm{N}$ Lat, $16^{\circ} 43^{\prime}$ E Long), near Zistersdorf, Lower Austria. Coll. 1960 and subm. by F. Felgenhauer, Inst. für Ur- und Frühgeschichte, Univ. of Vienna.

General Comment: dates agree with expectation.

\section{VRI-73. Gaiselberg 1}

Charcoal from $1.20 \mathrm{~m}$ deep pit filled with earth.

\section{VRI-74. Gaiselberg 3}

Wood (oak?) fragments from palisade of medieval defense building (rampart), loess, depth $1.6 \mathrm{~m}$ below grass-grown surface.

VRI-82. Gaiselberg 4

A.D. 1210

Charcoal from $1.20 \mathrm{~m}$ deep pit filled with burned remnants.

VRI-83. Traismauer, N.ö.

$<\mathbf{2 0 0}$

Wood from oldest part of "Gutscher-Mill" taken at rebuilding. Traismauer ( $48^{\circ} 21^{\prime} \mathrm{N}$ Lat, $15^{\circ} 44^{\prime} \mathrm{E}$ Long), Lower Austria. Coll. 1966 by F. R. Prokop; subm. by H. Stiglitz, Österreichisches Archäol. Inst., Univ. of Vienna.

\section{VRI-93. Pitten, N.ö.}

$3050 \pm 90$

1100 B.c.

Charcoal sample from pyre of Bronze-age burial (Grave 5) from W slope at S edge of Pitten ( $47^{\circ} 43^{\prime} \mathrm{N}$ Lat, $16^{\circ} 13^{\prime} \mathrm{E}$ Long), Lower Austria, Parzelle 372. Beam of pyre in situ, depth $1 \mathrm{~m}$, lying on loamy brownish earth, covered with same material. Wood structure clearly visible. Cross section of beam shows thin charcoal surface around calcareous earth kernel. Coll. 1967 by S Schmiedt; subm. by F. Hampl, N. ö. Landesmus., Vienna. Comment (F.H.): date agrees with expectation.

\section{VRI-22. Hallstatt-Lahn, O.ö.}

$1860 \pm 110$

Wood lifted from layer of Roman culture, $1.8 \mathrm{~m}$ deep, in area of Roman settlement Friedelfeld (Morton, 1965), Hallstatt-Lahn $\left(47^{\circ} 34^{\prime}\right.$ N Lat, $13^{\circ} 59^{\prime}$ E Long), Upper Austria. Coll. 1962; subm. by F. Morton, Mus. Hallstatt. Comment: date consistent with expectation.

VRI-99. Hallstatt, Grüner-Werk, O.ö.

Wood (Picea and Abies) remnants of Prehistoric fire stick in so-called "Heidengebirge," former salt mine pits filled with loam, clay, and different salts; Grüner-Werk, Salzberg, Hallstatt $\left(47^{\circ} 34^{\prime} \mathrm{N}\right.$ Lat, $13^{\circ} 39^{\prime}$ E Long), Upper Austria. Coll. 1966 by Schauberger; subm. by F. Morton. Comment (F.M.): date points to La Tène. 
Gosaumiihle series, 0 . $\ddot{\text { o. }}$

Wood samples (Larix) from adits of thermal spring "Warmes Wasser," presently buried below slope of debris (Morton, 1932, 1944; Hehenwarter and Morton, 1956), between Gosaumühle and Steeg (47 $37^{\prime} \mathrm{N}$ Lat, $13^{\circ} 38^{\prime} \mathrm{E}$ Long), Upper Austria, at $\mathrm{W}$ shore of lake Hallstättersee. Subm. by F. Morton.

General Comment: age of adits unknown. Existence of thermal water, known by tradition, rediscovered by "vapor holes" at snow-capped slope in winter and by ice-free water region at shore due to thermal water influx below water surface. Adit 1, reached by sinking a shaft in frozen debris, could be followed ca. $70 \mathrm{~m}$. No spring was found. Later, Adit 2 was discovered ca. $2 \mathrm{~m}$ below the 1st. Immediately after sampling, Adit 2 collapsed. Spring could not be found.

VRI-44. Gosaumühle 1

$730 \pm 100$

Sample from plank of Adit 1. Coll. 1965 by H. Pramesberger.

\section{VRI-65. Gosaumühle 2}

$440 \pm 110$

Sample from propping post of Adit 2. Coll. 1965 by R. Zahler. Comment: younger than VRI-44. Supposedly, spring sank in course of time. Adit 2 was necessary to get spring again.

\section{Mondsee series 2, 0. 0̈.}

Samples of wooden piling from lake-dwelling remnants lifted from bottom of lake Mondsee at See am Mondsee $\left(47^{\circ} 49^{\prime} \mathrm{N}\right.$ Lat, $13^{\circ} 27^{\prime}$ E Long), Upper Austria, depth $2 \mathrm{~m}$. Subm. by J. Reitinger, O. Ö. Landesmus., Linz. Comment: dates consistent with Mondsee culture (Franz and Weninger, 1927; Reitinger, 1966).

VRI-37. See am Mondsee 1

$4910 \pm 130$

Coll. 1965 by diver Papacek.

\section{VRI-68. See am Mondsee 2}

2960 B.C.

Coll. 1966 by Unterwasserarbeitsgemeinschaft Salzburg.

\section{VRI-119. See am Mondsee 3}

$$
4750 \pm 90
$$

2800 B.C.

Coll. 1967 by Unterwasserarbeitsgemeinschaft Salzburg.

\section{Mondsee series 3, O. Ö.}

Samples of wooden pilings from lake-dwelling remnants near St. Lorenz (475 $50^{\prime} \mathrm{N}$ Lat, $13^{\circ} 22^{\prime} \mathrm{E}$ Long), Upper Austria, at lake Mondsee, at present, completely buried in fluvial deposits and over grown with grass. Subm. by J. Reitinger.

General Comment: no artifacts; supposedly belongs to Mondsee culture (Franz and Weninger, 1927). Dates are contradictory. 
VRI-23. St. Lorenz am Mondsee

$1280 \pm 100$

Sample excavated from deposits of rivulet Griesler Ache from ca. I m depth, below subsoil water of this rivulet. Coll. 1961 by J. Reitinger.

VRI-71. St. Lorenz-Achort

A.D. 1120

$830 \pm 80$

Sample excavated from slope of rivulet Mühlbach from ca. $80 \mathrm{~cm}$ depth, $20 \mathrm{~cm}$ below water level of this rivulet. Coll. 1966 by Unterwasserarbeitsgemeinschaft Salzburg.

\section{VRI-64. Imurium-Moosham, Salzburg}

$1700 \pm 80$

Charcoal (Abies) embedded in loam below terrazzo in Roman settlement Imurium-Moosham $\left(47^{\circ} 06^{\prime} \mathrm{N}\right.$ Lat, $13^{\circ} 42^{\prime} \mathrm{E}$ Long), Salzburg. Coll. 1965 and subm. by R. Fleischer, Österr. Archäol. Inst., Univ. of Vienna. Comment (R.F.): sample dates floor laying (Fleischer, 1964-65).

\section{VRI-7. Krungl, Steiermark}

$7250 \pm 470$

\section{B.C.}

Wood of larch trunk lifted from $2 \mathrm{~m}$ under surface in Celtic grave field, Krungl near Mitterndorf (47 $34^{\prime} \mathrm{N}$ Lat, $13^{\circ} 56^{\prime} \mathrm{E}$ Long), Salzkammergut, Styria. Coll. 1949 by Deopito; subm. by F. Morton. Comment (F.M.): unexpectedly high age; trunk does not belong to grave field.

VRI-84. Weiz, Steiermark

Wooden nail from hewn post excavated in mixing zone of Pleistocene ballast and recent soil ca. $2 \mathrm{~m}$ deep at Hauptplatz of Weiz $\left(47^{\circ}\right.$ 13' N Lat, 15 ${ }^{\circ} 38^{\prime} \mathrm{E}$ Long), Styria. Coll. 1966 and subm. by L. Farnleitner, Archivalienpfleger, Weiz. Comment (L.F.): date does not contradict supposed connection between sample and rebuilding of tabor of Weiz (1644 and 1685) if age limit corrected for de Vries effect (Suess, 1965).

\section{VRI-92. Dölsach, Osttirol}

$$
2130 \pm 80
$$

Charred wood in deposits of loamy sand with stones up to $30 \mathrm{~cm}$ diam. of rivulet Gödnacher Bach excavated from $3 \mathrm{~m}$ depth. Fluvial deposits of Gödnacher Bach ca. $50 \mathrm{~m}$ thick laying over alluvium of $\mathrm{R}$. Drau, Dölsach $\left(46^{\circ} 50^{\prime} \mathrm{N}\right.$ Lat, $12^{\circ} 50^{\prime} \mathrm{E}$ Long), East Tyrol. Sample stems from artificial fireplace. Coll. 1967 and subm. by G. Platzer, Amt der Tiroler Landesregierung, Kulturbauamt Lienz. Comment (G.P.): date indicates age of fluvial deposits in valley of Lienz and age of settlement at Dölsach.

\section{B. Europe, Asia, South America}

VRI-30. Neuss, West Germany

$2060 \pm 110$ 110 B.C.

Charcoal from Roman pottery furnace excavated at Neuss $\left(51^{\circ} 12^{\prime}\right.$ N Lat, $06^{\circ} 42^{\prime}$ E Long), Rheinland, West Germany. Coll. by H. Petri- 
kovits; subm. by R. Pittioni. Comment (R.P.): date agrees with expectation.

\section{Egolzwil series, Switzerland}

Charcoal samples from Neolithic dwelling places Egolzwil-3 and Egolzwil-4 (47 $11^{\prime} \mathrm{N}$ Lat, 05 $41^{\prime} \mathrm{E}$ Long), Wauwilermoos, Lucerne, Switzerland. Dwelling places belong to Older Cortaillod culture (Vogt, 1951; Troels-Smith, 1956). Subm. by R. Pittioni.

\section{VRI-28. Egolzwil-3}

$5620 \pm 130$

Coll. 1952 by E. Vogt. Comment (R.P.): date too young.

\section{VRI-29. Egolzwil-4}

3670 B.C.

Coll. 1954 by E. Vogt. Comment (R.P.): date too young. Sample probably contaminated by reed roots.

\section{VRI-66. Mt. Gabriel, Ireland}

$3450 \pm 120$

1500 B.c.

Charcoal from Prehistoric copper mines on Mt. Gabriel $\left(51^{\circ} 32^{\prime}\right.$ $45^{\prime \prime} \mathrm{N}$ Lat, 09 31' 50" E Long), W County Cork, Ireland. Coll. 1966 by J. Jackson and Raftery; subm. by R. Pittioni. Comment (J.J.): sample is composite of 2 stratigraphic horizons (Jackson, 1968), separated by zone of fines, which can reach thickness of $30 \mathrm{~cm}$ and may conceivably represent appreciable period of time. Date must therefore be minimum; mines possibly belong to Early Bronze age, as suggested by field evidence from area, rather than to middle of Bronze age.

\section{VRI-40. Ephesos, Turkey}

\section{A.D. 700}

$1250 \pm 110$

Wood from tree, embedded in alluvial clay and mud above base of Artemision altar, $7 \mathrm{~m}$ deep, in subsoil water. Ephesos $\left(37^{\circ} 55^{\prime} \mathrm{N}\right.$ Lat, $27^{\circ} 19^{\prime}$ E Long), Turkey. Coll. 1965 and subm. by A. Bammer, Österr. Archäol. Inst., Univ. of Vienna. Comment (A.B.): date limits destruction of Artemision altar.

\section{Pisco-Paracas series, Perú}

Charcoal in burned layer ca. $50 \mathrm{~cm}$ deep under accumulation of pecten shells (Kjökken Möddinger) near Salinas de Otuma in desert S of Pisco-Paracas (13 $49^{\prime}$ S Lat, $76^{\circ} 14^{\prime} \mathrm{W}$ Long), Perú. Coll. 1964 and subm. by H. Kinzl, Geog. Inst., Univ. of Innsbruck.

General Comment (H.K.): dates in agreement with knowledge on Kjökken Möddinger from Peruvian coast.

VRI-36. Otuma 1

$3650 \pm 130$

Charcoal.

1700 B.C.

VRI-121. Otuma 2

$3460 \pm 90$

1510 B.c.

Pecten shells. Pretreatment: surface removed with hydrochloric acid. 
Date lists:

British Museum I

Copenhagen I

Copenhagen III

Copenhagen VI

Groningen II

Heidelbers: I

Lund I

Rome II

Stockholm I

Uppsala I

USGS I

USGS VII

\section{REFFRENCES}

Barker and Mackey, 1959

Tauber, 1953

Tauber, 1960

Tauber, 1964

de Vries, Barendsen, and Waterbolk, 1958

Münnich, 1957

Håkansson, 1968

Alessio, Bella, and Cortesi, 1964

Östlund, 1957

Olsson, 1959

Suess, 1954

Rubin, 1964

Aario, L., 1945, Ein nachwärmezeitlicher Gletschervorstoss in Oberfernau in den Stubaier Alpen: Acta Geog. (Helsinki), v. 9, no. 3, p. 1-31.

Abele, G., 1964, Die Fernpasstalung und ihre morphologischen Probleme: Tübinger Geog. Studien, v. 12.

Alessio, M. F., Bella, F., and Cortesi, C., 1964, University of Rome carbon-14 dates II: Radiocarbon, v. 6, p. 77-90.

Barker, H. and Mackey, C. J., 1959. British Museum natural radiocarbon measurements I: Radiocarbon, v. 1, p. 81-86.

Ebers, E., 1963, Kann die begrabene Landoberfläche von Hörmating letztinterglaziales Alter besitzen?: Oberrhein. Geol. Ver., Jber. u. Mitt. Bd. 45, p. 88.

Felber, H., 1962, Über die Leistungsfähigkeit einer C-14-Altersbestimmungsapparatur: Sitzungsber. d. Österr. Akad. d. Wiss., v. 170, p. 85-103.

___ 1965, Altersbestimmungen nach der Radiokohlenstoffmethode am Institut für Radiumforschung und Kernphysik I: Sitzungsber. d. Österr. Akad. d. Wiss., v. 174, p. $175-186$.

1966, Über eine Methode zur systematischen Entstörung kernphysikalischer elektronischer Messanordnungen: Acta Phys. Austriaca, v. XXIII, p. 397-399.

1966. Altersbestimmungen nach der Radiokohlenstoffmethode am Institut für Radiumforschung und Kernphysik II: Sitzungsber. d. Österr. Akad. d. Wiss., v. 175 , p. 59-64.

1967. Altersbestimmungen nach der Radiokohlenstoffmethode am Institut für Radiumforschung und Kernphysik III: Sitzungsber. d. Österr. Akad. d. Wiss., v. 176 , p. $117-119$.

1968. Altersbestimmungen nach der Radiokohlenstoffmethode am Institut für Radiumforschung und Kernphysik IV: Sitzungsber. d. Österr. Akad. d. Wiss., v. 177, p. 113-121.

Felber, H. and Vychytil, P., 1962, Messanordnung für energiearme $\beta$-Strahlung geringer Intensität, speziell zur Alters-Bestimmung nach der Radiokohlenstoffmethode: Sitzungsber. d. Österr. Akad. d. Wiss., v. 170, p. 180-205.

Fleischer, R., 1964-65, Imurium-Moosham, 1. vorläufiger Bericht über die Ausgrabungen in den Jahren 1964-65: Jahresh. d. Österr. Archäol. Inst., v. 47, Beiblatt 207 f.

Franz, L. and Weninger, J., 1927, Pfahlbauten am Mondsce: Wien.

Friesinger, H. and Mitscha-Märheim, H., 1968, Die Ausgrabungen in der Wallburg "Schanze" in Thunau bei Gars, N.Ö.: Österr. Zeitschr. f. Kunst- u. Denkmalpflege, v. XXII, p. 48.

Fromme, G., 1957, Der Waldrückgang im Oberinntal (Tirol): Mitt. d. Forstlichen Bundesversuchsanstalt Mariabrunn, no. 54.

Håkansson, S., 1968, University of Lund radiocarbon dates I: Radiocarbon, v. 10, p. 36-54.

Hehenwarter, E. and Morton, F., 1956, Weitere Beobachtungen am "Warmen Wasser" am Hallstätter See: Archiv f. Hydrobiol., v. 52, p. 449-450.

Heuberger, H., 1966 Gletschergeschichtliche Untersuchungen in den Zentralalpen zwischen Sellrain- und Ötztal: Wiss. Alpenvereinshefte, v. 20, p. 12.

Jackson, J. S., 1968, Bronze age copper mines of Mount Gabriel, West County Cork, Ireland: Archaeol. Austriaca, v. 43, p. 92.

Kral, F. and Mayer, H., 1968, Pollenanalytische Überprüfung des Urwaldcharakters in den Naturwaldreservaten Rothwald und Neuwald (Niederösterreichische Kalkalpen): Forstwiss. Centralblatt, 87. Jg., p. 129-192. 
Mavr, F., 1964, Untersuchungen über Ausmass und Folgen der Klimaund Gletscherschwankungen seit dem Beginn der postglazialen Wärmezeit: Zeitschr. f. Geomorph., N.F., v. 8 , p. $257-285$.

1968, Besprechung Nr. 32: Petermanns Geog. Mitt., no. 2.

1968a, Über den Beginn der Würmeiszeit im Inntal bei Innsbruck: Zeitschr.

f. Geomorph., N.F., v. 12, p. 256-295.

$1968 \mathrm{~b}$, Postglacial glacier fluctuations and correlative phenomena in the Stubai Mountains, Eastern Alps, Tyrol, in: Richmond, G. M. (ed.), Glaciation of the Alps: Univ. of Colorado Studies, Ser. in Earth Sci., no. 7, p. 167-177.

1969, Die postglazialen Gletscherschwankungen des Mont-Blanc-Gebietes: Zeitschr. f. Geomorph. (Berlin), INQUA-Heft.

Morton, F., 1932, Das "Warme Wasser" am Hallstätter See: Archiv f. Hydrobiol., v. XXIV, p. 543-546.

1944, Eine neue Warmwasserquelle am Hallstätter See: Archiv f. Hydrobiol., v. XXXIX, p. 690-692.

1965, Die Grabungen in der römischen Niederlassung in der Lahn (Hallstatt) 1954-1956 und 1964: Jahrb. d. O.Ö. Musealvereines, v. 110, p. 172-203.

Münnich, K. O., 1957, Heidelberg natural radiocarbon measurements I: Science, v. 126, p. $194-199$.

Novotny, B., 1962, Luzianska skupina a pociatky mal'ovanej keramiky na Slovensku: Bratislava.

Olsson, I. U., 1959, Uppsala natural radiocarbon measurements I: Radiocarbon, v. 1, p. $87-102$.

östlund, G., 1957a, Stockholm natural radiocarbon measurements I: Science, v. 126, p. $493-497$.

Pittioni, R., 1954, Urgeschichte des Österreichischen Raumes: Wien.

Quitta, H., 1967, Radiocarbondaten und die Chronologie des mittelund südosteuropäischen Neolithikums: Ausgrabungen und Funde, v. 12, p. 115.

Reitinger, J., 1966, Vorbericht über die Pfahlbauforschungen am Mondsce: Archaeol. Austriaca, v. 40.

Rubin, M., 1964, U.S. Geological Survey radiocarbon dates VII: Radiocarbon, v. 6, p. $37-76$

Suess, H. E., 1954, U.S. Geological Survey radiocarbon dates I: Science, v. 120, p. 467. 1965, Secular variations of the cosmic-ray-produced Carbon 14 in the atmosphere and their interpretations: Jour. Geophys. Research, v. 70, no. 23 p. $5937-5952$.

Tauber, H., 1953, Copenhagen natural radiocarbon measurements I: Science, v. 118 , p. $6-9$. v. 2, p. 5-11. Copenhagen natural radiocarbon measurements III: Radiocarbon,

1964, Copenhagen radiocarbon dates VI: Radiocarbon, v. 6, p. 215-225.

Troels-Smith, J., 1956, Neolithic period in Switzerland and Denmark: Science, v. 124, p. 876-879.

Vogt, E., 1951, Das steinzeitliche Uferdorf Egolzwil-3 (Kt. Luzern), Bericht über die Ausgrabung 1950: Zeitschr. schweiz. Arkaeol. u. Kunstgeschichte, v. 12, no. 4

de Vries, Hl., Barendsen, G. W., and Waterbolk, H. T., 1958, Groningen radiocarbon dates II: Science, v. 127, p. 129-137. 